\title{
Ultrasonic-Assisted Semi-Solid Forming Method and Microstructure Evolution of Aluminum/Copper Brazed Joints
}

\author{
Yin Liang ${ }^{1,2}{ }^{\oplus}$, Jiruan Pan ${ }^{3}$, Hua Zhang ${ }^{2}$, Peng Huang ${ }^{2}$, Jun Wang ${ }^{1}$, Yuxin Shi ${ }^{1}$ \\ and Limin Chen ${ }^{1, *}$ \\ 1 School of Information Engineering, Nanchang University, Nanchang 330031, China; \\ liangyin@ncu.edu.cn (Y.L.); ncudsp20@126.com (J.W.); hr667sy@yeah.net (Y.S.) \\ 2 School of Mechatronics Engineering, Nanchang University, Nanchang 330031, China; \\ robinkk4@gmail.com (H.Z.); ncuhp9090@163.com (P.H.) \\ 3 School of Mechanical Engineering, Tsinghua University, Beijing 100084, China; \\ pjl-dme@mail.tsinghua.edu.cn \\ * Correspondence: chenlimin@ncu.edu.cn
}

Received: 31 December 2019; Accepted: 3 February 2020; Published: 6 February 2020

\begin{abstract}
Aluminum/Copper dissimilar metal connection devices have been widely used in equipment manufacturing. Ultrasonic vibration assisted semi-solid brazing technology is beneficial to improve brazing quality by using the good flow ability and strong deformation resistance of brazing alloy when it is in a semi-solid state. In this study, a new ultrasound-assisted high-frequency induction brazing method was used to braze aluminum and copper dissimilar metals under non-vacuum conditions with non-prefabrication of brazing filler metal. In a short time, uniform semi-solid brazed joint was obtained. Detailed investigations on the effects of aluminum-substrate side (Abbreviated as $\mathrm{Al}$ side) heat dissipation rate and ultrasonic vibration duration on the microstructure evolution and mechanical properties of semisolid weld were conducted. The results show that the welding seam obtained by the modification method increases the microstructure uniformity of brazing joint.
\end{abstract}

Keywords: ultrasonic vibration; dissimilar metal; semi-solid status; brazing; microstructure evolution

\section{Introduction}

Due to their excellent corrosion resistance, high mechanical strength, and excellent electric and heat transfer performance, Aluminum and copper and their alloys have been widely used in electric power, cooling, chemical industry and aerospace fields [1-5]. In the process of equipment manufacturing, the connection problem of aluminum and copper dissimilar metals is often faced.

$\mathrm{Zn}-\mathrm{Al}$ alloy is a promising brazing filler alloy for $\mathrm{Al} / \mathrm{Cu}$ brazing [6-9]. The main advantage of the filler metal is that zinc metal and $\mathrm{Cu}$ and $\mathrm{Al}$ metal all had a very good solubility, which form good metallurgical combination easily, and the same time the $\mathrm{Zn}-\mathrm{Al}$ alloy has good toughness and corrosion resistance. The $\mathrm{Zn}-\mathrm{Al}$ filler [10] is a medium temperature solder and the eutectic temperature is about $380{ }^{\circ} \mathrm{C}$, which can basically adapt all $\mathrm{Al}$ alloy brazing [11] connection and can avoid stress cracks resulted from the high temperature brazing and substrate metals ablation. $\mathrm{Zn}$ alloy has good thermal and electrical conductivity, which meeting the needs of $\mathrm{Al} / \mathrm{Cu}$ connector performance. With the advantages of above-mentioned, the $\mathrm{Zn}-\mathrm{Al}$ filler brazing alloy of $\mathrm{Al} / \mathrm{Cu}$ dissimilar metals is increasingly become a hot research area.

From what has been discussed above, it can be seen that in brazing welding, semi-solid filler metal has many advantages: reducing connection temperature; getting isometric crystals and uniform microstructure of the joint whose strength can be achieved or close to the strength of the substrate 
metals. In addition, semi-solid brazing can deposit a large amount of filler metal in a single-pass brazing, which avoids smoke and splash [12-17].

Existing research [12-14,18-20] shows that using semi-solid brazing can increase the uniformity of brazing seam joint structure, but the research on ultrasound-assisted brazing of $\mathrm{Al} / \mathrm{Cu}$ dissimilar metals using non-prefabricated semi-solid $\mathrm{Zn}-22 \mathrm{Al}$ (Eutectic solder) as filler metal is rarely found.

Due to the heat and mass transfer characteristics [21], ultrasonic assisted method has been widely used in various kinds of metal welding [22] in recent years to improve the microstructure of the welding seam (including brazing seam).

So, a kind of non-vacuum ultrasound-assisted semi-solid Zn-22Al high-frequency induction brazing of $\mathrm{Al} / \mathrm{Cu}$ is adopted in this paper, herein referred to as semi-solid-state brazing with ultrasonic-assisted unilateral nucleation (abbreviated as TSBUAUN). Then, the influence of aluminum side heat dissipation rate and ultrasonic duration on the microstructure evolution and physical properties of semi-solid forming brazed seam joint are studied, which are of great significance for promoting the industrial application of $\mathrm{Al} / \mathrm{Cu}$ dissimilar metal connection.

The proposed TSBUAUN method can improve the uniformity of the brazing joint structure, and its forming mechanism can be extended to semi-solid brazing of other dissimilar metals, providing a method and theoretical support for new brazing technology and the design of dissimilar brazing solder.

\section{Experimental Materials and Methods}

The substrate materials used in the experiment are $6060 \mathrm{Al}$ provided by Henan Jiayuan Aluminum company (Zhengzhou, China) and T1 copper $(\mathrm{Cu})$ plate provided Zhongtian Copper Industry Co. LTD (Dongguan, China), and each size is $60 \mathrm{~mm} \times 20 \mathrm{~mm} \times 2 \mathrm{~mm}$. The detailed composition of the substrate materials are shown in Table 1. The filler metal is $\mathrm{Zn}-22 \mathrm{Al}$ provided by Xinrui China (Shengzhou, China) with a thickness of $0.3 \mathrm{~mm}$ and a size of $7 \mathrm{~mm} \times 20 \mathrm{~mm}$. Before the experiment, the surface of substrate metals and filler metal were polished, and the oxide film was removed. After grinding, the substrate metals were put into acetone and then washed with water bath ultrasonic for 15 min to avoid the impact of grease and impurities on the joint structure on the material surface. Then, the cut composite filler metal is coated with flux. The substrate metals and the composite filler metal are fixed in accordance with the structure shown in Figure 1.

Table 1. Chemical compositions of $6061 \mathrm{Al}$ alloy, $\mathrm{T} 1 \mathrm{Cu}$ alloy, and $\mathrm{Zn}-22 \mathrm{Al}$ alloy.

\begin{tabular}{|c|c|c|c|c|c|c|c|c|c|}
\hline Material & $\mathrm{Al}$ & $\mathrm{Fe}$ & $\mathrm{Cu}$ & Si & Mn & $\mathrm{Mg}$ & $\mathrm{Zn}$ & $\mathrm{Ti}$ & $\mathbf{P}$ \\
\hline $6061 \mathrm{Al}$ & Bal. & 0.7 & $0.15-0.4$ & $0.4-0.8$ & 0.15 & $0.8-1.2$ & 0.25 & 0.15 & \\
\hline $\begin{array}{c}\text { T1 Cu } \\
\text { Zn-22Al }\end{array}$ & 22 & $\leq 0.005$ & $\mathrm{CuAg} \geq 99.95$ & 1.5 & & & $\begin{array}{c}\leq 0.005 \\
76.5\end{array}$ & & $p<0.001$ \\
\hline
\end{tabular}

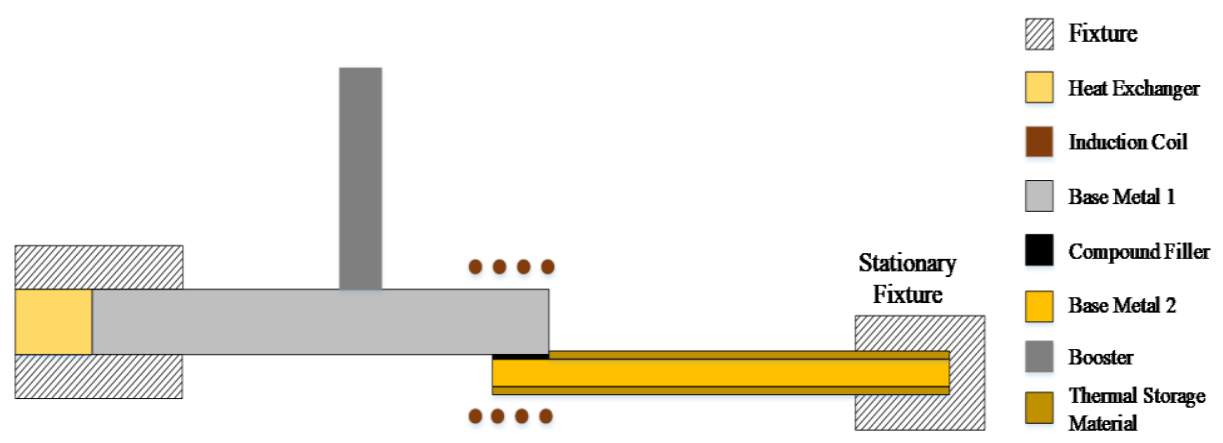

Figure 1. Schematic representation of bonding process for vibration brazing.

Brazing was carried out in atmospheric environment. The melting point of the brazing alloy $\mathrm{Zn}-22 \mathrm{Al}$ is about $450{ }^{\circ} \mathrm{C}$. The use of pure cesium salt of medium temperature flux in the brazing process can protect the brazing materials and help to break the oxidation film on the metals surface. 
The melting point of pure cesium salt is $445{ }^{\circ} \mathrm{C}$, which plays a role in the vicinity of the filler metal liquid temperature line of $450^{\circ} \mathrm{C}$. The melting of pure cesium flux (Xinrui, China) before that of filler metal helps to protect the welding joint.

In the experiments, SP-25B model high frequency induction heating equipment which produced by Shuangping Supply Power Technologies Company (Shenzhen, China) was used as the brazing heat source. It consists of signal source, induction coil and cooling equipment. Meanwhile, thermocouple was used for temperature measurement.

In order to investigate the influence of $\mathrm{Al}$ side heat dissipation rate as while as ultrasonic duration on semi-solid forming and brazing joint microstructure [18,23-27], different experiments were designed. Firstly, under the condition of keeping the ultrasonic vibration duration unchanged, we carried out several groups of experiments under the condition of $2 \mathrm{~K} / \mathrm{s}, 5 \mathrm{~K} / \mathrm{s}, 7 \mathrm{~K} / \mathrm{s}$ and $9 \mathrm{~K} / \mathrm{s}$ (here $\mathrm{K}$ is the unit of thermodynamic temperature, named Kelvin, Abbreviated as $\mathrm{K}$ and $\mathrm{K} / \mathrm{s}$ Represents the heat dissipation rate per second). Heat dissipation rate at $\mathrm{Al}$ side by adjusting the heat exchanger. Then, several groups of experiments under $0,2,4,6$, and $9 \mathrm{~s}$ ultrasonic vibration duration were carried out under the condition of the same heat dissipation rate on $\mathrm{Al}$ side.

The bonding cycle of heating, ultrasonic vibrating, solid/liquid ratio adjustment and Secondary ultrasonic dispersion and cooling are schematically illustrated in Figure 2.

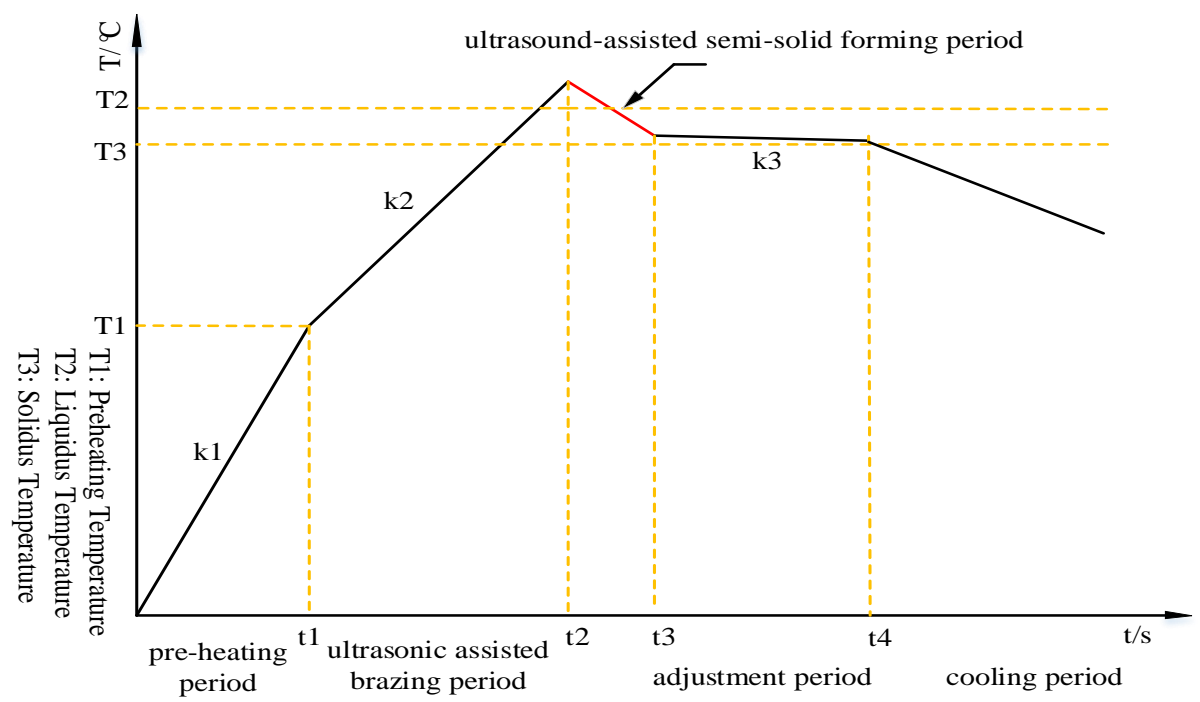

Figure 2. Sequence diagram of ultrasonic assisted one-side core semisolid brazing process.

After brazing, the samples were cut off along the width and each the section was polished with a series of metallographic sandpapers. The corrosion status of each polished specimen was observed under an optical microscope (OM) (GX71, Olympus corporation, Tokyo, Japan). The corrosion method was as follows: aluminum substrate material was corroded by $2 \%$ hydrofluoric acid, and copper substrate material was corroded by $3 \mathrm{~g}$ of $\mathrm{FeCl}_{3}$ powder and $2 \mathrm{~mL}$ hydrochloric acid and $96 \mathrm{~mL}$ anhydrous ethanol. The corrosion time was about $5 \mathrm{~s}$.

In order to further investigate the effect of semisolid process on microstructure and microstructure composition of brazed joints, the polished samples were observed by a scanning electron microscope (SEM, Quanta FEG 200, FEI Corporation, Hillsboro, OR, USA). Meanwhile, in order to explore the mechanism of the semi-solid process on the mechanical properties of brazed joints, the shear tensile strength (tensile rate of $1 \mathrm{~mm} / \mathrm{min}$ ) of each sample was measured on a universal mechanical tester.

In addition, experiments of common non-ultrasonic vibration brazing of $\mathrm{Al}-\mathrm{Cu}$ were carried out to compare with the new method-TSBUAUN 


\section{Results and Discussion}

\subsection{Typical Interfacial Microstructure of the Al/Zn-22Al/Cu Brazed Joint}

Optical microscope images of the interfacial microstructure of brazed joints by different brazing methods are shown in Figure $3 a, b$ are the weld microstructure obtained by the common brazing process and ultrasonic assisted brazing process respectively.
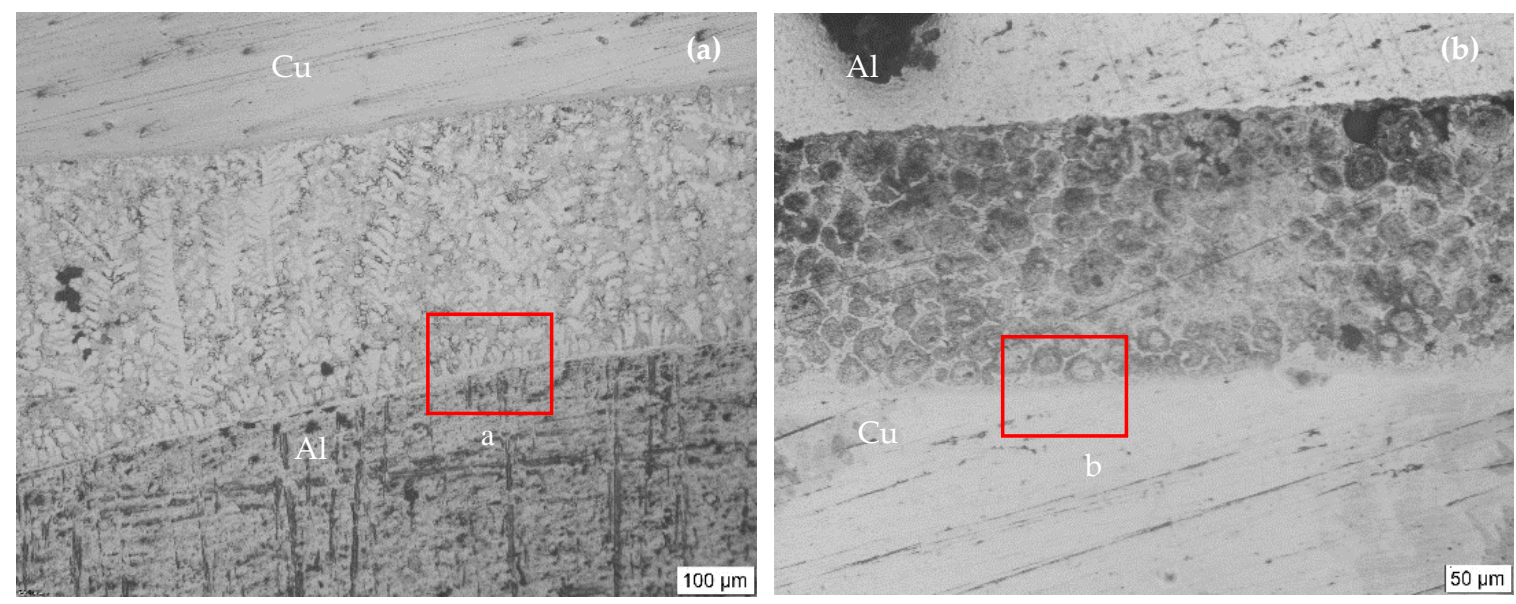

Figure 3. (a) brazing $\mathrm{Al} / \mathrm{Cu}$ without ultrasonic; (b) semi-solid brazing $\mathrm{Al} / \mathrm{Cu}$ with ultrasonic.

There are obvious differences in microstructure between the two kinds of brazing samples. The microstructure of brazed joint of common brazing sample in Figure 3a is mainly dendrite and fringe eutectic. The number of fringe eutectic tissues on the $\mathrm{Cu}$ - substrate- side (Abbreviated as $\mathrm{Cu}$ side) is larger than that on the Al side, which conforms to the diffusion law of Cu element.

In Figure $3 b$ the microstructure of the TSBUAUN sample is mainly spherulite and fringe eutectic. The density of spherulite on the $\mathrm{Al}$ side is higher than that on the $\mathrm{Cu}$ side. Through graphic analysis of the corroded semi-solid specimen, it can be found that the core of the spherulite is more easily corroded than other parts of the semi-solid specimen.

Meanwhile, from TSBUAUN sample we can see there are obvious differences in corrosion resistance of spherulite cores on both sides of $\mathrm{Cu}$ and $\mathrm{Al}$. $\mathrm{Cu}$ side spherulite core has better corrosion resistance than that of $\mathrm{Al}$ side. Under the condition of $\mathrm{Al}$ side supercooling, the weld formed dense $\alpha-\mathrm{Al}$ columnar crystal and Large dendrites. Active heat dissipation on the Al side aggravated the imbalance of weld temperature and was beneficial to dendrite growth. The average length of dendrites can reach 200 to 300 microns under certain conditions.

Under the action of appropriate $\mathrm{Al}$ side heat dissipation rate and appropriate ultrasonic vibration duration semi-solid state in brazed joints was achieved. The diameter of semi-solid spherulites is mainly distributed between 25 and 40 microns, and the average size is about 35 microns.

By comparing Figure $3 a, b$, it was found that there was an obvious transition layer (about $10 \mu \mathrm{m}$ ) on the $\mathrm{Cu}$ side of the common brazing sample, while the transition layer of the ultrasonic assisted brazing sample was very thin $(0.5-0.8 \mu \mathrm{m})$.

The optical microstructure of the brazed joint of common brazing samples (Figure 4a), SEM microstructure (Figure $4 \mathrm{~b}$ ) and line-scan component analysis (Figure 4c) showed that the microstructure of common brazing was mainly composed of $\alpha$-Al phase dendrite and $\mathrm{Zn}$-Al eutectic. The rose-like intermetallic compounds are mainly distributed at grain boundaries. According to SEM/EDS results, the following two intermetallic compounds were identified: CuZn5- $\varepsilon$ phase (light gray zone) and Al5Cu4Zn-T' phase (dark gray zone). 

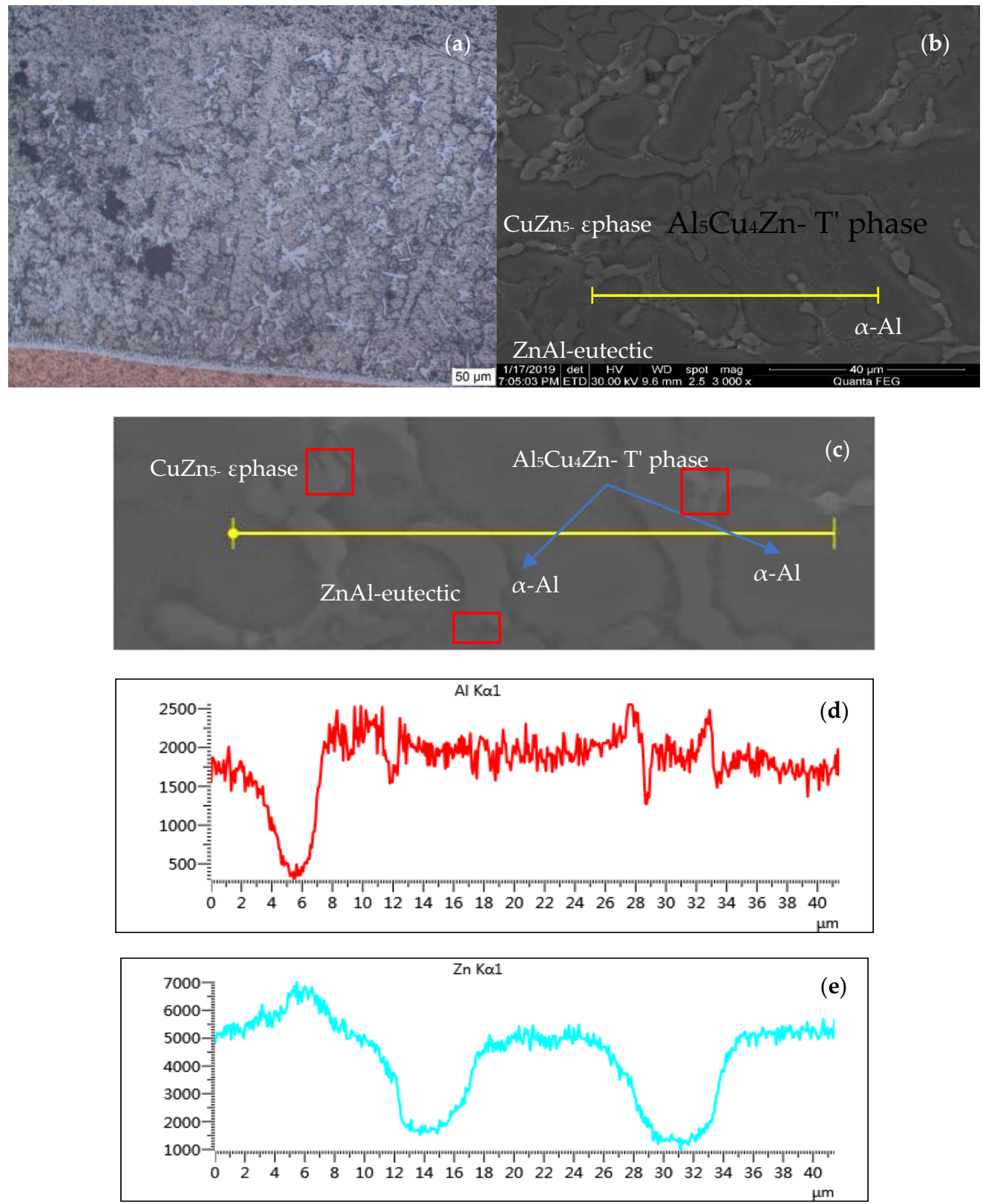

Figure 4. The dendrite microstructure OM diagram, SEM morphology diagram and line scan diagram of the brazed joint area of common sample: (a) OM morphology of dendrite in brazed zone; (b) SEM morphology of dendrite structure in brazed zone; (c) Linear scanning composition of dendrites in brazed joint microstructure; (d) Line scan for Al composition; (e) Line scan for Zn composition.

Under the ultrasonic-assisted semi-solid forming process, due to non-equilibrium solidification, striated eutectic was produced at the rapid cooling rate during the brazing process, and the number of eutectic tissues on the $\mathrm{Cu}$ side was significantly larger than that on the $\mathrm{Al}$ side. Due to the forced convection generated by ultrasonic waves, the dendrite-Al phase fragmentation was promoted, and the typical spherical structure composed of semi-solid particles was formed, as in Figure 5. 

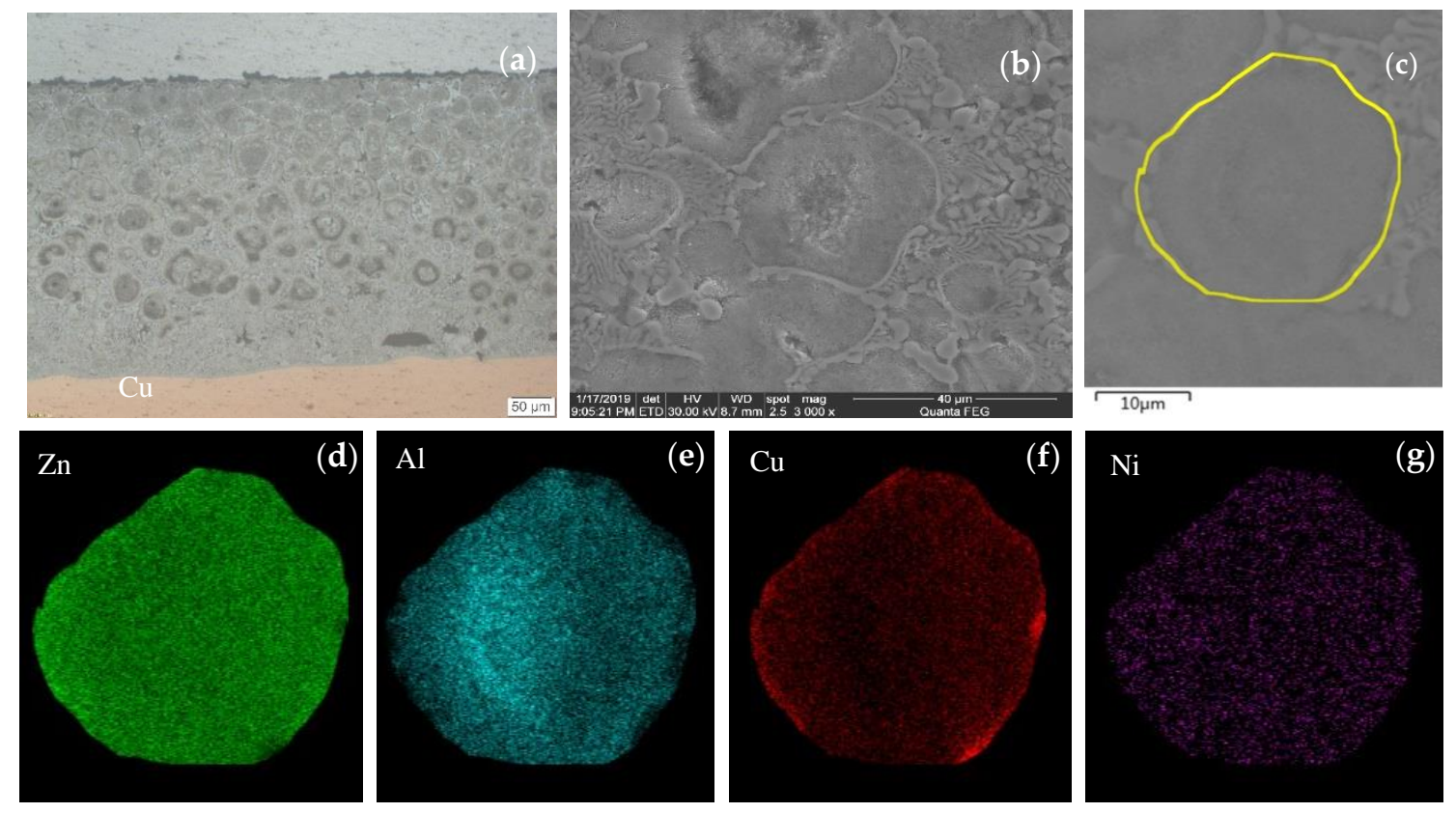

Figure 5. Spherulite OM morphology, SEM morphology, EDS layered image and composition distribution of ultrasonic-assisted semi-solid sample: (a) OM morphology of spherulite in the brazed joint zone; (b) SEM morphology of dendrite structure in the brazed joint zone; (c) EDS hierarchical images in spherulite; (d) Zn distribution in spherulite; (e) Al distribution in spherulite; (f) Cu distribution in spherulite; (g) Ni distribution in spherulite.

\subsection{Influence of Aluminum Side Heat Dissipation Rate on Semi-Solid Forming and Microstructure Evolution of Brazed Joints}

In order to explore the influence of different $\mathrm{Al}$ side heat dissipation rates on ultrasonic assisted brazing weld seams, we set four kinds of $\mathrm{Al}$ side heat dissipation rates of 2, 5, 7, and $9 \mathrm{k} / \mathrm{s}$ by adjusting the heat exchange equipment at $\mathrm{Al}$ plate side.

When the ultrasonic vibration duration is kept at $6 \mathrm{~s}$, the microstructure appearance of each brazing seam sample obtained under different Al-side heat dissipation rates is shown in Figure 6.

As long as ultrasonic vibration is carried out, there are no large tree dendrites in the weld microstructure of brazing samples with different $\mathrm{Al}$-side heat dissipation rate. Instead, there are rose-like crystals, columnar crystals and spherulites with relatively regular distribution, as can be seen in Figure 6.

The size of columnar crystal on $\mathrm{Al}$ side increases with the increase of heat dissipation rate on $\mathrm{Al}$ side. When the heat dissipation rate on the $\mathrm{Al}$ side increases to $9 \mathrm{~K} / \mathrm{s}$, some columnar crystals on the Al side have grown secondary crystal axes, as shown in region $\mathrm{d} 1$ of Figure $6 \mathrm{~d}$. Through careful observation of the weld microstructure in Figure $6 \mathrm{~d}$, we found that the columnar crystal size on the $\mathrm{Cu}$ side was much smaller than that firstborn on the $\mathrm{Al}$ side, but dendrite microstructure could be observed in the local area (d2). When the heat dissipation rate on the Al side increases to $9 \mathrm{~K} / \mathrm{s}$, the elongated columnar crystals generated in the weld joint are not conducive to the formation of semi-solid state spherulites.

In order to achieve a better semi-solid-state effect, we gradually reduced the heat dissipation rate on the $\mathrm{Al}$ side. When the rate dropped to $7 \mathrm{~K} / \mathrm{s}$, the size of primary columnar crystals on $\mathrm{Al}$ side decreases and there is no obvious dendrite tendency, meanwhile the size of primary columnar crystals on $\mathrm{Al}$ side decreased, and there was no obvious dendrite tendency. In Figure $6 \mathrm{c}$, the dendrite degree of columnar crystals of $C$ region presents an obvious gradient. Most columnar crystals distributed on the $\mathrm{Cu}$ side have secondary axis, but there is no fully developed dendrite structure in the weld seam. 

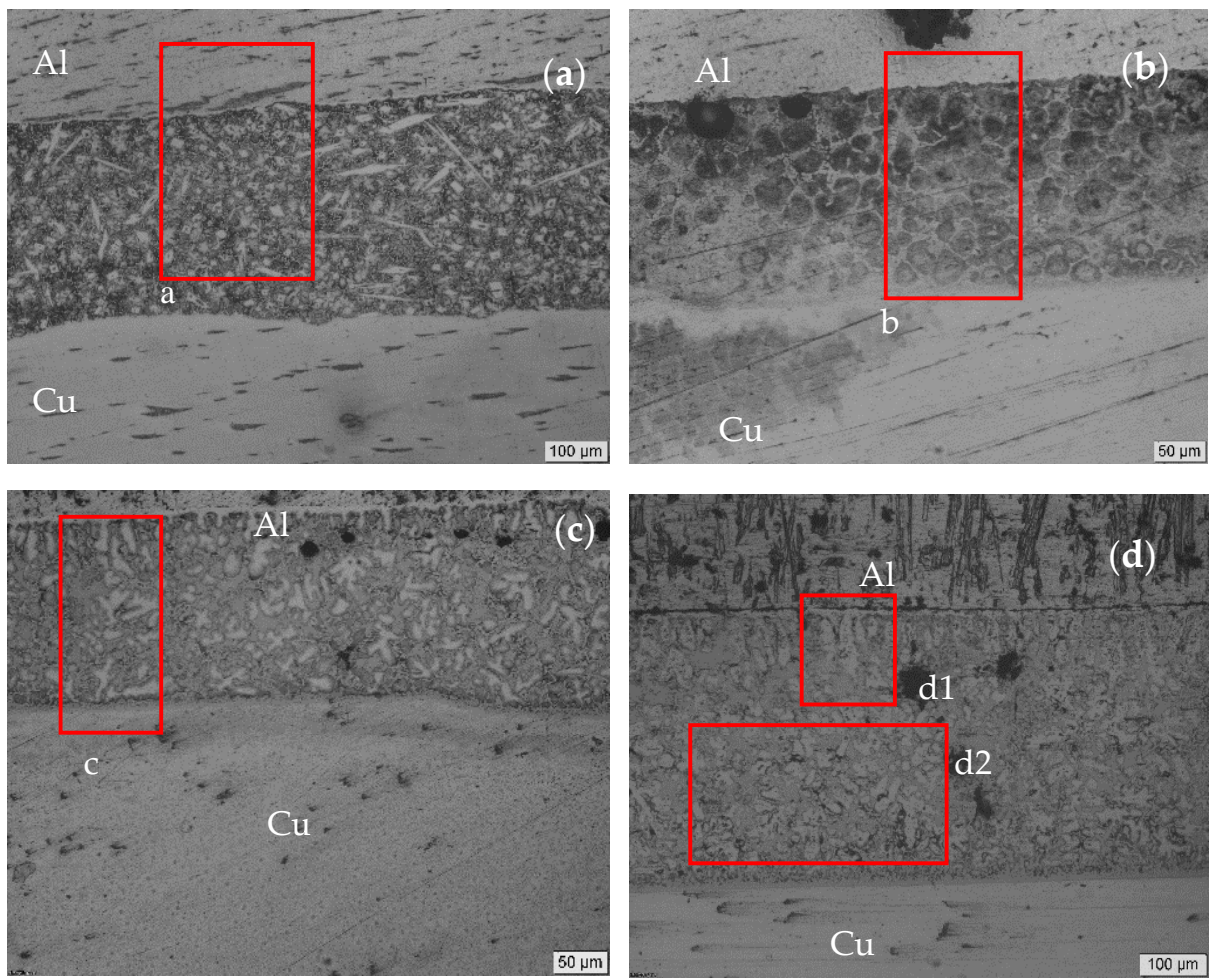

Figure 6. Microstructure of brazed joints under different Al-substrate-side heat dissipation rate: (a) Al-side heat dissipation rate $2 \mathrm{~K} / \mathrm{s}$; (b) Al-side heat dissipation rate $5 \mathrm{~K} / \mathrm{s}$; (c) Al-side heat dissipation rate $7 \mathrm{~K} / \mathrm{s}$; (d) Al-side heat dissipation rate $9 \mathrm{~K} / \mathrm{s}$.

It is concluded that the heat dissipation rate of $7 \mathrm{~K} / \mathrm{s}$ on $\mathrm{Al}$ side is still not conducive to semi-solid spherulites forming. Therefore, the Al-side heat dissipation rate was gradually reduced. Under the combined action of ultrasonic vibration and the $\mathrm{Al}$-side heat dissipation rate down to $5 \mathrm{~K} / \mathrm{s}$, the semi-solid state of weld microstructure was well realized, as shown in Figure $6 \mathrm{~b}$, where the spherulites in the weld seam have a good sphericity, and these ball spherulites diameters are mainly distributed between 20 and 35 microns. Meanwhile, the spherulite density on both sides of the substrate metal differs.

In order to comprehensively explore the effect of $\mathrm{Al}$ side heat dissipation rate on the microstructure of weld joint, we further reduce the heat dissipation rate of the $\mathrm{Al}$ side to the rate of $2 \mathrm{~K} / \mathrm{s}$. This time, in the welding joint seam, there were no thick columnar crystals or good spherulites on the $\mathrm{Al}$ side, but a large number of rose crystals formed (the copper-aluminum compounds are shown in a region of Figure 6a. We used Image software to conduct statistical analysis on the size of weld microstructure and crystal distribution obtained at different $\mathrm{Al}$-side heat dissipation rates. The size of crystals and their distribution in weld microstructure were clearly demonstrated under different $\mathrm{Al}$-side heat dissipation rates, as shown in Figure 7. Under the action of ultrasonic vibration, the influences of different Al-side heat dissipation rates on weld microstructure are quite different. 
(a)

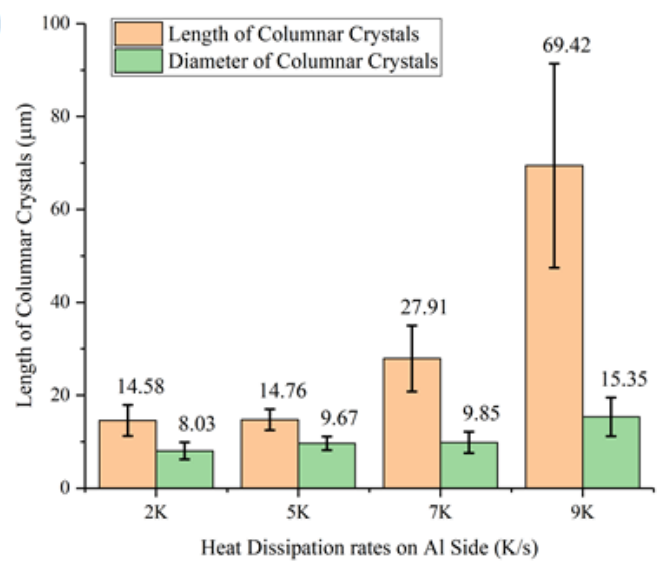

(b)

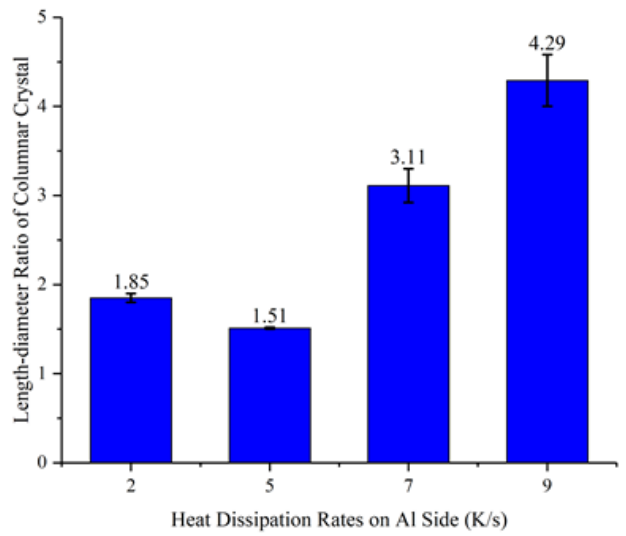

Figure 7. (a) columnar crystal length and diameter under four $\mathrm{Al}$ side heat dissipation rates $(\mathrm{K} / \mathrm{s})$ at 2 $\mathrm{K} / \mathrm{s}, 5 \mathrm{~K} / \mathrm{s}, 7 \mathrm{~K} / \mathrm{s}$ and $9 \mathrm{~K} / \mathrm{s}$; (b) columnar crystal length-diameter ratio of Al-side heat dissipation rate $(\mathrm{K} / \mathrm{s})$ at $2 \mathrm{~K} / \mathrm{s}, 5 \mathrm{~K} / \mathrm{s}, 7 \mathrm{~K} / \mathrm{s}$ and $9 \mathrm{~K} / \mathrm{s}$.

\subsection{Effect of Ultrasonic Duration on Semi-Solid Forming and Microstructure Evolution of Corresponding Weld Seams}

The Al-side heat dissipation rate and ultrasonic vibration are two key factors of semi-solid forming. The Al-side heat dissipation rate affects the morphology of the primary microstructure of the welding joint, while the appearance of weld joint microstructure is also related to ultrasonic vibration. We set a series of ultrasonic vibration duration (the first segment of ultrasound) to explore the mechanism of semi-solid forming under different ultrasonic duration, which are set as $0 \mathrm{~s}, 2 \mathrm{~s}, 4 \mathrm{~s}, 6 \mathrm{~s}$ and $9 \mathrm{~s}$ respectively in experiments. Under the optimal Al-side heat dissipation rate of $5 \mathrm{k} / \mathrm{s}$, the metallography pictures of welding joints applied different ultrasonic vibration duration are shown in Figure 8.

By observing the metallographic diagrams in Figure 8, it is not difficult to find that, under suitable Al-side heat dissipation conditions at rate of $5 \mathrm{~K} / \mathrm{s}$, large dendrites grew from $\mathrm{Al}$ substrate material in the brazing process without adding ultrasonic vibration, as shown in Figure 8a. A Strong perturbation or agitation is required in the semi-solid forming process, and the weld joint microstructure of the sample with $2 \mathrm{~s}$ ultrasound no longer has large dendrite structure. In the selection area b in Figure 8, the coarse equiaxed crystal structure appears near the Al-substrate material, with each crystal diameter of 25 30 microns, and also find that a certain number of columnar crystal structure below the coarse equiaxed crystal structure, with a length of about 50 microns.

When Ultrasonic vibration duration is $2 \mathrm{~s}$, it can't achieve better semi-solid structure forming, or even can't be called "semi-solid brazed joint". Figure $8 \mathrm{c}$ shows the brazed seam microstructure under $4 \mathrm{~s}$ ultrasonic vibration duration, which has basically achieved semi-solid state. and the process of primary equiaxed grain nucleation and being sheared can even be observed in the box selected area c.

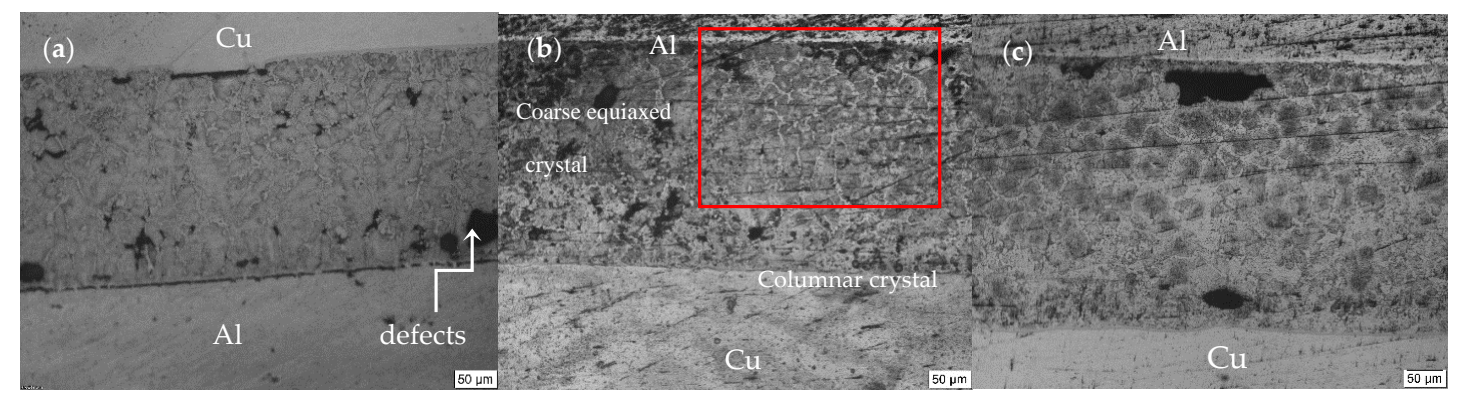

Figure 8. Cont. 


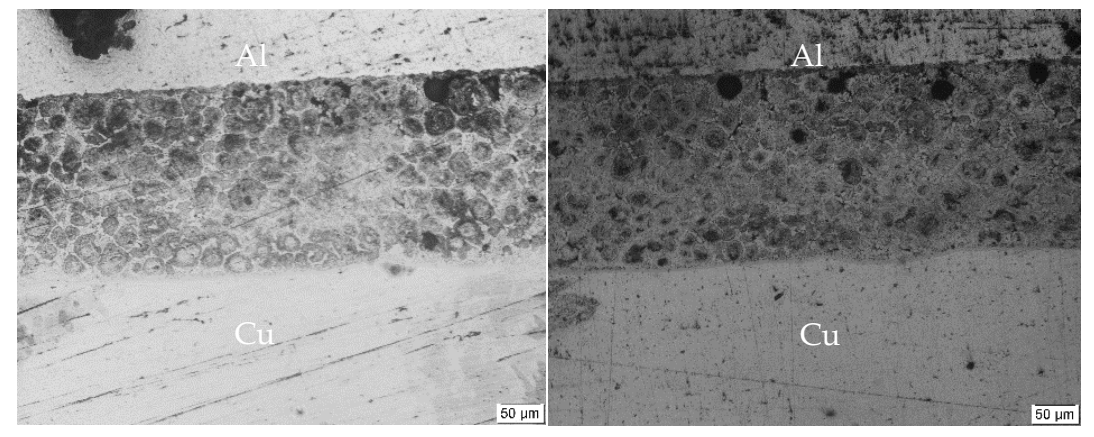

Figure 8. Microstructure of welds with different ultrasonic vibration duration: (a) $0 \mathrm{~s}$; (b) $2 \mathrm{~s}$; (c) $4 \mathrm{~s}$; (d) $6 \mathrm{~s} ;(\mathbf{e}) 9 \mathrm{~s}$.

At the Al-side heat dissipation rate of $5 \mathrm{~K} / \mathrm{s}$, the primary nucleation crystals of welding joint on the $\mathrm{Al}$ side, which shown in the selected area c have spherulite characteristics. Although ultrasonic vibration $4 \mathrm{~s}$ has basically achieved semi-solid welding seam, spherulite sphericity and density still have room for improvement. With the increase of ultrasonic vibration time to $6 \mathrm{~s}$, the density of spherulite in weld increased greatly and the density of spherulite in the weld joint has been greatly improved, which means semi-solid forming effect is ideal, as shown in Figure 8, area d. However, the increase of ultrasonic vibration time will not always provide a positive effect for semi-solid forming, and more deformed spherulites appear in the weld seam of ultrasonic vibration sample of $9 \mathrm{~s}$, as shown in area e Figure 8, which means that too long ultrasonic vibration time will have a negative impact on the semi-solid forming effect.

In order to better characterize the effect of ultrasonic vibration on the sphericity and distribution of semi-solid spherulite of the microstructure of joints, we used image software to analyze the sphericity and spherulite density of samples with different ultrasonic vibration durations, as shown in Figure 9.
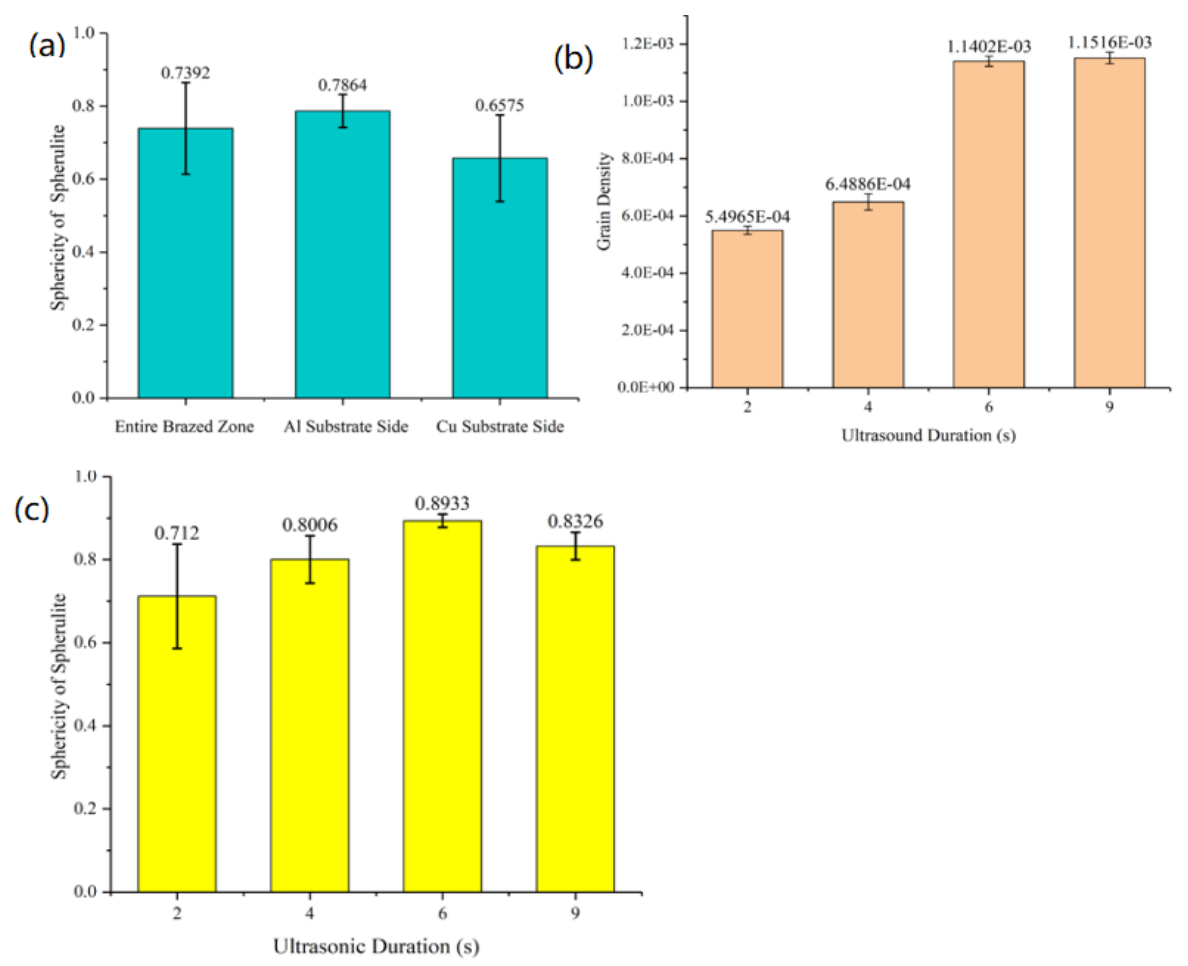

Figure 9. (a) spherulite sphericity of each weld seam area when ultrasonic vibration time is $2 \mathrm{~s}$; (b) grain density under different ultrasonic duration of $2 \mathrm{~s}, 4 \mathrm{~s}, 6 \mathrm{~s}$ and $9 \mathrm{~s}$; (c) spherulite sphericity under different ultrasonic duration of $2 \mathrm{~s}, 4 \mathrm{~s}, 6 \mathrm{~s}$ and $9 \mathrm{~s}$. 
Based on the above analyses, the aluminum side heat dissipation rate and ultrasonic duration had significant effects on semi-solid forming and the microstructure evolution of joints.

\section{Conclusions}

A reliable semi-solid state brazing joint of Copper connected to aluminum was successfully obtained using a new technique for non-vacuum ultrasound-assisted non-prefabricated semi-solid high-frequency induction brazing. The microstructure evolution and physical properties of $\mathrm{Al} / \mathrm{Zn}-22 \mathrm{Al} / \mathrm{Cu}$ joints were studied. Based on the achieved results, the conclusions are summarized as follows:

- Through a large number of cross tests, it was observed that when the ultrasonic time lasted $6 \mathrm{~s}$ and the heat dissipation degree on the aluminum side was $5 \mathrm{k} / \mathrm{s}$, a better semi-solid forming effect was achieved, the spherulite density was large, and the weld structure was uniform.

- When the ultrasonic duration is $6 \mathrm{~s}$, the effect of different heat dissipation rate on the microstructure of welding seam varies greatly. With the increase of heat dissipation rate on the Al side, the size of columnar crystal on the $\mathrm{Al}$ side keeps increasing. When the heat dissipation rate on the $\mathrm{Al}$ side reaches $9 \mathrm{~K} / \mathrm{s}$, some columnar crystals on the $\mathrm{Al}$ side have already grown secondary crystal axes. We gradually began to reduce the heat dissipation rate on the $\mathrm{Al}$ side from $9 \mathrm{~K} / \mathrm{s}$. When the supercooling rate drops to $7 \mathrm{~K} / \mathrm{s}$, the size of primary columnar crystals on $\mathrm{Al}$ side decreases and there is no obvious dendrite tendency. Further, $7 \mathrm{~K} / \mathrm{s} \mathrm{Al}$ side heat dissipation rate is still not conducive to semi-solid forming. Thus, we continue to reduce the $\mathrm{Al}$ side heat dissipation rate to $5 \mathrm{~K} / \mathrm{s}$. The joint action of ultrasonic vibration and $\mathrm{Al}$ side heat dissipation rate of $5 \mathrm{~K} / \mathrm{s}$ achieves the perfect semi-solid weld structure. Further reduce the heat dissipation rate of $\mathrm{Al}$ side cooling equipment. There were no thick columnar crystals or spherulites in the Al side, but a large number of rose crystals were formed. So far, under a certain ultrasonic duration, the semi-solid forming effect is good when the heat dissipation rate of $\mathrm{Al}$ side is $5 \mathrm{~K} / \mathrm{s}$. The weld organization is uniform, and the shear strength of the weld point reaches a maximum of $65.3 \mathrm{Mpa}$.

- Under $5 \mathrm{~K} / \mathrm{s}$ of the heat dissipation rate, the brazing process does not add in brazed joint ultrasonic vibration with $\mathrm{Al}$ parent metal as the basal bulky dendrite, add $2 \mathrm{~s}$ in ultrasonic sample brazing microstructure is no longer has a huge dendritic structure, and obtain the good effect of semi-solid forming can't even call the weld microstructure of semi-solid. With the increase of ultrasonic vibration time to $4 \mathrm{~s}$, the weld structure of the sample has basically achieved semi-solid state, and the process of primary isometric crystal nucleation and shearing can even be observed in the box selection area. With the increase of ultrasonic vibration time to $6 \mathrm{~s}$, the density of spherulite in the weld was greatly improved. The semi-solid forming effect is relatively ideal. However, the increase of ultrasonic vibration time will not always provide a positive effect for semi-solid forming, and the ultrasonic vibration time continues to increase. This means that the ultrasonic vibration time is too long to have a negative impact on the semi-solid forming effect.

- Compared with common brazing, the TSBUAUN brazing method changes the distribution and morphology of brazing intermetallic compounds, and the number of rose-like crystals is significantly reduced with fragmentation (thickness: $0.5-0.8 \mathrm{~m}$ ). After fragmentation, rose-like intermetallic compounds become monolayer phase wrapped in the outer layer of $\alpha$-Al phase. It is proven that the microstructure and intermetallic compound are changed by ultrasonic and the heat dissipation in the TSBUAUN process.

Author Contributions: Conceptualization, P.H. and J.W.; Formal analysis, Y.L.; Investigation, Y.L. and Y.S.; Project administration, H.Z.; Resources, J.P. and H.Z.; Supervision, J.P.; Validation, P.H.; Visualization, P.H. and Y.S.; Writing—original draft and revising, Y.L.; Writing-review and editing, all the authors; Writing-revising, L.C. and Y.L. All authors have read and agreed to the published version of the manuscript.

Funding: This project is supported by the National key R\&D program (Grant No. 2018YFB1305305), and the National Natural Science Foundation of China (Grant No. U1731118). 
Conflicts of Interest: The authors declare no conflict of interest.

\section{References}

1. Niu, Z.; Ye, J.; Huang, J.; Yang, H.; Yang, J.; Chen, S. Interfacial structure and properties of Cu/Al joints brazed with Zn-Al filler metals. Mater. Charact. 2018, 138, 78-88. [CrossRef]

2. Wang, X.-G.; Yan, F.J.; Li, X.-G.; Wang, C.-G. Induction diffusion brazing of copper to aluminum. Sci. Technol. Weld. Join. 2017, 19, 1-6.

3. Sahin, M. Effect of surface roughness on weldability in aluminum sheets joined by cold pressure welding. Ind. Lubr. Tribol. 2008, 5, 249-254. [CrossRef]

4. Saeid, T.; Abdollah-Zadeh, A.; Sazgari, B. Weldability and mechanical properties of dissimilar aluminum-copper lap joints made by friction stir welding. J. Alloy. Compd. 2010, 2, 652-655. [CrossRef]

5. Gulenc, B. Investigation of interface properties and weldability of aluminum and copper plates by explosive welding method. Mater. Des. 2008, 1, 275-278. [CrossRef]

6. Naka, M.; Hafez, K.M. Applying of ultrasonic waves on brazing of alumina to copper using Zn-Al filler alloy. J. Mater. Sci. 2003, 16, 3491-3494. [CrossRef]

7. Zhang, M.; Lin, Y.-B.; Jiang, H.-L. Effect of Al on Zn-Al Filler Metal Wettability on Pure Copper Surface. Adv. Mater. Res. 2012, 538, 196-199. [CrossRef]

8. Ji, H.; Chen, H.; Li, M. Effect of ultrasonic transmission rate on microstructure and properties of the ultrasonic-assisted brazing of Cu to alumina. Ultrason. Sonochem. 2017, 3, 491-495. [CrossRef]

9. Xu, H.; Xing, Q.; Zeng, Y. Semisolid stirring brazing of SiCp/A356 composites with Zn27Al filler metal in air. Sci. Technol. Weld. Join. 2011, 6, 483-487. [CrossRef]

10. Urena, A.; Gil, L.; Escriche, E.; Gómez de Salazar, J.M.; Escalera, M.D. High Temperature Soldering of Si C Particulate Aluminum Matrix Composites (series 2000) Using Zn-Al Filler Alloys. Sci. Technol. Weld. Join. 2001, 6, 1-11. [CrossRef]

11. Uremia, A.; de Salazar, J.G.; Escalera, M.D.; Fernandez, M.I. Study of the Braze-ability of Aluminum Matrix Composites. Weld. J. 1997, 6, 92-102.

12. Shi, L.; Yan, J.; Peng, B.; Han, Y. Deformation behavior of semi-solid Zn-Al alloy filler metal during compression. Mater. Sci. Eng. A 2011, 22, 7084-7092. [CrossRef]

13. Pola, A.; Tocci, M.; Kapranos, P. Microstructure and properties of semi-solid aluminum alloys: A literature review. Metals 2018, 3, 181. [CrossRef]

14. Xu, Z.; Li, Z.; Lei, X. Reduction of intermetallic compounds in ultrasonic-assisted semi-solid brazing of $\mathrm{Al} / \mathrm{Mg}$ alloys. Sci. Technol. Weld. Join. 2018, 24,1-8. [CrossRef]

15. Xu, Z.; Li, Z.; Peng, B.; Ma, Z.; Yan, J. Application of a new ultrasonic-assisted semi-solid brazing on dissimilar $\mathrm{Al} / \mathrm{Mg}$ alloys. Mater. Lett. 2018, 228, 72-76. [CrossRef]

16. Xu, H.; Zhou, B.; Du, C.; Luo, Q.; Chen, H. Microstructure and properties of joint interface of semisolid stirring brazing of composites. J. Mater. Sci. Technol. 2012, 12, 1163-1168. [CrossRef]

17. Yu, X.; Xing, W.-Q.; Ding, M. Ultrasonic semi-solid coating soldering 6061 aluminum alloys with Sn-Pb-Zn alloys. Ultrason. Sonochem. 2016, 31, 216-221. [CrossRef]

18. Flemings, M.C. Behavior of metal alloys in the semi-solid state. Metall. Mater. Trans. A 1991, 5, $270-292$.

19. Thadela, S.; Mandal, B.; Das, P.; Roy, H.; Lohar, A.K.; Samanta, S.K. Rheological behavior of semi-solid TiB2 reinforced Al composite. Trans. Nonferrous Met. Soc. China 2015, 25, 2827-2832. [CrossRef]

20. Wang, S.-C.; Qi, W.-J.; Zheng, K.-H.; Zhou, N.; Li, L. Microstructure and mechanical property of rheoforged A356 aluminum alloy in semisolid state. Forg. Stamp. Technol. 2011, 36, 127.

21. Gondrexon, N.; Cheze, L.; Jin, Y.; Legay, M.; Tissot, Q.; Tissot, Q.; Hengl, N.; Talansier, E. Intensification of heat and mass transfer by ultrasound: Application to heat exchangers and membrane separation processes. Ultrason. Sonochem. 2015, 25, 40-50. [CrossRef] [PubMed]

22. Krajewski, A.; Włosiński, W.; Chmielewski, T.; Kołodziejczak, P. Ultrasonic-vibration assisted arc-welding of aluminum alloys. Bull. Pol. Acad. Sci. Tech. Sci. 2012, 60, 841-852. [CrossRef]

23. Xia, C.-Z.; LI, Y.-J.; Wang, J.; Ma, H.-J. Microstructure and phase constitution near interface of $\mathrm{Cu} / \mathrm{Al}$ vacuum brazing. Mater. Sci. Technol. 2007, 23, 815-818. [CrossRef]

24. Yong, X.; Ji, H.; Li, M.; Kim, J. Ultrasound-induced equiaxial flower-like CuZn5/Al composite microstructure formation in Al/Zn-Al/Cu joint. Mater. Sci. Eng. A 2014, 594, 135-139. 
25. Swallowe, G.M.; Field, J.E.; Rees, C.S.; Duckworth, A. A photographic study of the effect of ultrasound on solidification. Acta Metall. 1989, 37, 961-967. [CrossRef]

26. Zhang, Y.; Zhang, K.; Liu, G.; Xu, J.; Shi, L.; Cui, D.; Cui, B. The formation of rosette phase structural evolution during the reheating and semisolid casting of AlSi7Mg Alloy. J. Mater. Process. Technol. 2003, 137, 195-200. [CrossRef]

27. Sumitomo, T.; Stjohn, D.; Steiberg, T. The shear behavior of partially solidified Al-Si-Cu alloys. Mater. Sci. Eng. A 2000, 286, 18-29. [CrossRef]

(C) 2020 by the authors. Licensee MDPI, Basel, Switzerland. This article is an open access article distributed under the terms and conditions of the Creative Commons Attribution (CC BY) license (http://creativecommons.org/licenses/by/4.0/). 